\title{
Problem-Based Learning Achievement of K-12 Students Participating in a Nanotechnology Hands-on Works Exhibition in Taiwan
}

\author{
Meng-Kao Yeh ${ }^{1}$, Hsiao-Chin Hsieh ${ }^{2}$, Shu-Hsian Chang ${ }^{3}$, Rongshun Chen ${ }^{1}$, Hung-Yin Tsai ${ }^{1}$ \\ Department of Power Mechanical Engineering ${ }^{1}$, Center for General Education ${ }^{2}$, Library ${ }^{3}$ \\ National Tsing Hua University, Hsinchu, Taiwan, ROC
}

\begin{abstract}
Nanotechnology is one of the newly research subjects in the science field. School teachers teach students about the knowledge of nanotechnology; thus, developing appropriate instructional modules of nanotechnology have become an important issue. In this paper, a Nanotechnology hands-on works exhibition was held in the library of National Tsing Hua University, Taiwan. By problem-based learning, K-12 teachers design instructional activities to guide students on hands-on works using nanotechnology concepts. The problem-based learning achievement of K-12 teachers and students participating in this science activity was studied by giving pretest and post test questionnaires.
\end{abstract}

\section{Introduction}

Nanotechnology is one of the newly developing subjects in the science field, and developing appropriate instructional modules of nanotechnology have become an attractive and important issue in local schools, Taiwan.

"Nano" is a unit, meaning one billionth $\left(10^{-9}\right)$ meter, and is called one nanometer (nm). The first use of this concept found in "nano-technology" was in "There's Plenty of Room at the Bottom", a talk given by physicist Richard Feynman at an American Physical Society meeting at Caltech on December 29, 1959. Feynman described a process by which the ability to manipulate individual atoms and molecules might be developed, using one set of precise tools to build and operate another proportionally smaller set, and so on down to the needed scale[1]. The application of nanotechnology is under developing in many fields, from academic community to daily life in many countries. Many industries, such as electronics, pharmaceuticals, cosmetics, and textiles, use the concepts of nanotechnology to improve their products and some products, like stain-resistant clothing, transparent zinc-oxide-based sunscreen, and scratch-resistant automobile paint, are already on the market. Nanotechnology research involves the study, control, fabrication of matter across science and engineering disciplines and researchers explore an extremely diverse range of phenomena [2]. PCAST (President's Council of Advisors on Science and Technology) has predicted that nanotechnology will be applied to areas for water purification, medical diagnostics, targeted drug therapies, and solar cells by 2020 [3]. Nanotechnology will be one of the most popular sciences in the future.

To let more people know nanotechnology, Taiwan government conduct the "Nanotechnology human resource development program" for several years. Since the industry of nanotechnology will be prosperous in the future; thus, growing up the talents of nanotechnology is very important $[4,5]$. Under this situation, it is essential to teach children to know about nanotechnology when they are in primary and secondary schools. Because of the age and immature mind, children in elementary school may not understand the difficult concepts of nanotechnology. Providing quality nanotechnology instruction and the proper curriculum design for young students is a challenge [2]. Therefore we have to get kids to learn the basic nanotechnology by designing interesting games, science exhibitions, or integrated courses. When students are in secondary school, they are more mature. They can understand some concepts of nanotechnology, and teachers could develop more appropriate instructional materials for them. Above all, we can train students with the knowledge of nanotechnology by school education. Besides, the promotion of knowledge of nanotechnology to general public is also important.

In this work, we collaborated with K-12 teachers, and designed the teaching materials and instructional methods for nanotechnology courses. In order to arouse K-12 students' interests about nanotechnology, a nanotechnology hands-on works exhibition was held in library of National Tsing Hua University, Taiwan. In this science activity, we observe K-12 students' behavior and their performance by testing their knowledge of nanotechnology before and after their participation of the science activity. Our goal is to know the learning achievement of K-12 students in 
nanotechnology education by visiting the science activity.

Bloom has classified questions to six items: knowledge, comprehension, application, analysis, synthesis, and evaluation [6]. In this work, we designed the pretest and post test questionnaires according to the problem-based learning theory. We let K-12 students to find answers by their own. They could discuss with their classmates, teachers, or guiders during the visiting time. The questions in the pretest questionnaire stressed the knowledge and comprehension ability for nanotechnology. On the other hand, questions in the post test questionnaire emphasized on the application and synthesis capability.

\section{Problem-based learning}

Problem-based learning (PBL) has been widely introduced in medical education [7] for problems to induce and develop students' thinking and problem solving abilities. Problem-based learning is based on theories of constructivism, situated learning, and cooperative learning [8]. The learning method concentrates on group workings, discussions, selflearning and learning knowledge by daily life. Teachers guide students to find answers by themselves. Some researchers have indicated that PBL has been generally used in science education recently, because it could lead students to break through the traditional thought, and to improve students' ability of creativity [9, 10]. Using a scenario or problem could prompt students to acquire knowledge by experience in relation to a real problem [11]. Different from the traditional learning style, PBL encouraged learners to use self directed learning skills. In problem-based learning, teachers play a role of "facilitator". They provide suggestions to students, and assist students to obtain their subject knowledge [12]. D. Kelly has indicated that there are 7 steps for implementing PBL: clarify and decide the problems, analysis the problems, identify study priorities for the scenario, formulate learning objectives for the problems, individual study, and identify areas for improvement [12]. This kind of learning method could strengthen students' concept for learning a new science subject.

In this study, K-12 teachers and students did the nanotechnology hands-on works together. In order to arouse students' interests on nanotechnology handson works, teachers designed many instructional activities for nanotechnology. According to Piaget's theory of constructivism, individuals can construct new knowledge from their experiences [13]. Students learned nanotechnology concepts and how to make creative hands-on works through teachers' guidance step by step. By asking questions and scenario design, K-12 teachers enhanced their students' interests on nanotechnology, and students used the basic concept they learned to do the hands-on works.

\section{Science exhibition}

Recently, constructivism has been a trend in education. Many researchers think that learning is controlled by learners, and instructors are just the supervisor and assistant $[14,15]$. Science exhibition activities play a vital role in science education. Science exhibition has been one of the activities for education and culture exchange around the world. This kind of activity can motivate students' imagination and creativity. Teachers must assist their students to develop science works, according to the foundation of science theory [16]. Attending the science exhibition, students can learn many things outside their formal class. They must find their topics interested, and then study the related subjects, or collect the information. This kind of learning method can enhance more knowledge acquisition [17].

Dale's Cone of Experience (see Figure 1) showed that the different learning experience has the influence of learning achievement. According to Dale's research, the least effective method at the top, involves learning from information presented through verbal symbols, for example, listening to spoken words. The most effective methods at the bottom, involves direct, purposeful learning experiences, such as hands-on or field experience. Direct purposeful experience represents everyday life [18].

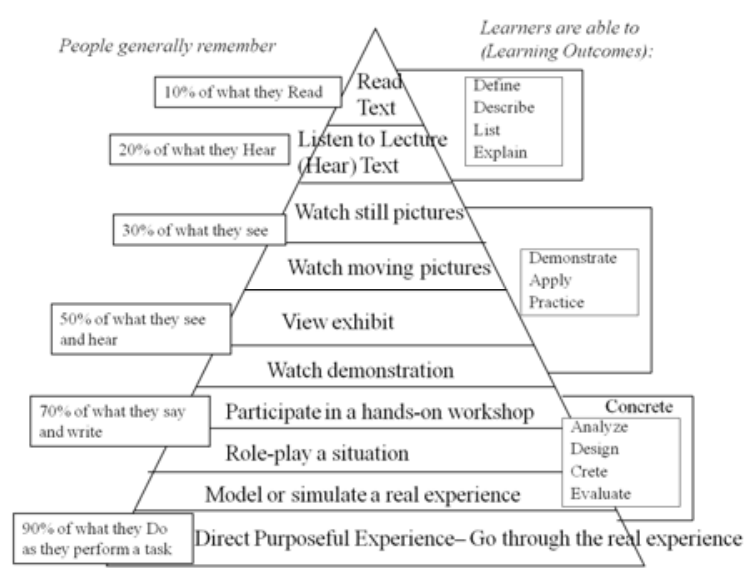

Figure 1. Dale's Cone of Experience [19]

In this paper, Nanotechnology hands-on works exhibition was held in the library of National Tsing Hua University, Taiwan. We asked teachers and K12 students to build their own exhibition works about nanotechnology, and their works have been exhibited for one month. Students and teachers used the concept of nanotechnology to do the hands-on works. Students learned the nanotechnology concepts by doing hands-on works and many 
students' hands-on works could be used in daily life. This science activity showed different built models, posters, and multiple-media exhibitions with nanotechnology concepts. The purpose of this activity is to let more people know "What is nanotechnology", and to let teachers and students to be more interested in learning nanotechnology knowledge by visiting this science exhibition. The goal of this study is to know the learning achievement of K-12 students participating nanotechnology hands-on works exhibition.

\section{Research design}

In this work, the subject is K-12 school students and teachers who attend the science exhibition of nanotechnology in the library of National Tsing Hua University, Taiwan. This study uses the questionnaire analysis. To know the level of visitors' nanotechnology knowledge, a pretest questionnaire was given before they visit the exhibition. After visiting the exhibition, they do the posttest to test their improvement from this science exhibition. There are 402 persons answered the questionnaire, the effective questionnaire are 394.

In this paper, pretest and posttest questionnaires have been designed. Both pretest and posttest questionnaires had the same questions, but the order of question was different. There are 16 questions in the questionnaire, including 8 true-false questions and 8 multiple choices ones. Every question is related to the knowledge of nanotechnology. Before answering 16 questions, testers filled the information about their position and organization/school. All the questionnaires are anonymous. Figure 2 is a part of the questionnaire.

\section{Results and discussion}

The followings are the results obtained from the pretest and post test questionnaires. The statistics of population is given in Table 1 from this study.

Table 1.The statistics of population

\begin{tabular}{|l|l|l|l|l|l|}
\hline Subject & $\begin{array}{l}\text { Primary } \\
\text { school }\end{array}$ & $\begin{array}{l}\text { Junior } \\
\text { high } \\
\text { school }\end{array}$ & $\begin{array}{l}\text { Senior } \\
\text { high } \\
\text { school }\end{array}$ & adult & total \\
\hline Teacher & 13 & 12 & 16 & 3 & 44 \\
\hline Student & 195 & 150 & 5 & 0 & 350 \\
\hline Total & 208 & 162 & 21 & 3 & 394 \\
\hline
\end{tabular}

To study the improvement of testers' knowledge of nanotechnology before and after visiting this science exhibition, discarding four uncompleted data, a box-and-whisker plot was obtained as shown in Figure 3. The mean and median values of pre-test and post-test are showed in Table 2 .

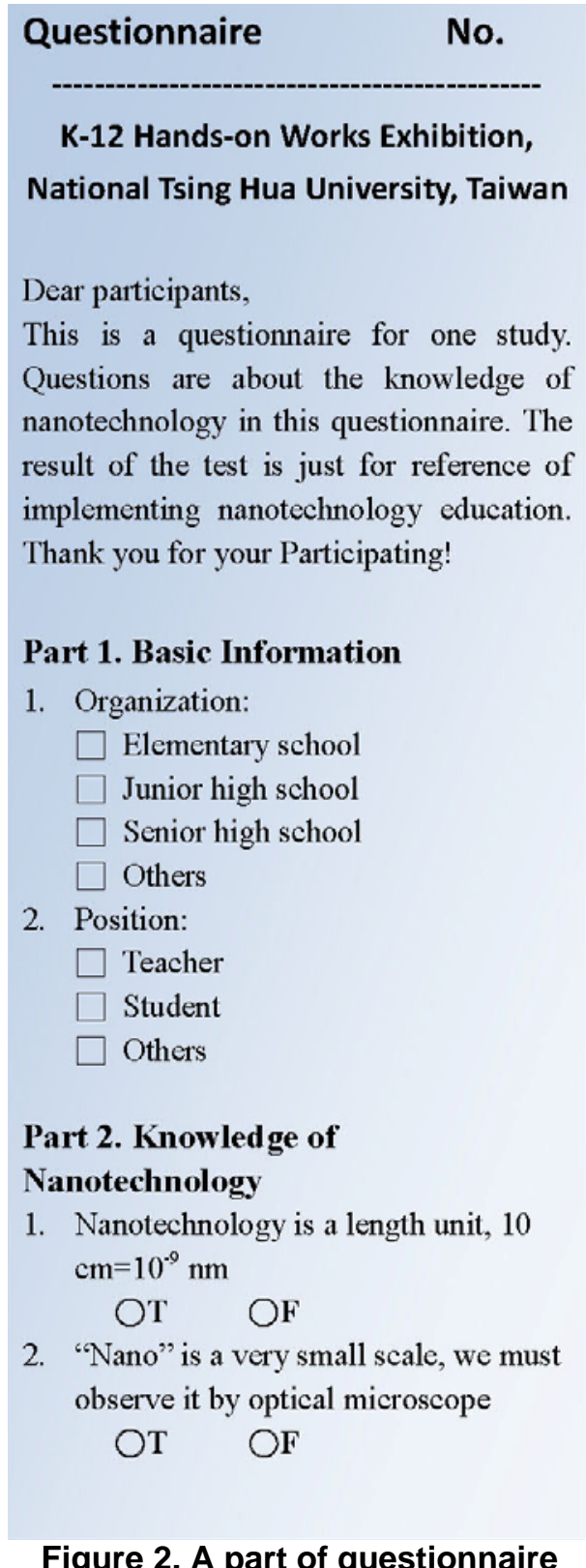

Table 2. Mean and median values of pretest and post-test

\begin{tabular}{|l|l|l|}
\hline & Pretest & Post-test \\
\hline Mean & 9.3858 & 11.2919 \\
\hline Min & 1 & 2 \\
\hline Median & 9 & 12 \\
\hline Max & 16 & 16 \\
\hline
\end{tabular}

Comparing the mean value and median value of pre-test to post-test, the grade of post-test is higher than that of pretest obviously. In the box-andwhisker plot, Figure 3, the box presented the grade distribution of $50 \%$ population. In the graph, $50 \%$ of the post-test grade is much higher than that of pretest. The relationship of pretest grade and posttest grade is 0.613 , and $\mathrm{P}<0.001$ in statistics. The 
paired t test for two samples shows that post-test grade is higher than pretest one with obvious difference. Also, each teacher and student group has obvious improvement.

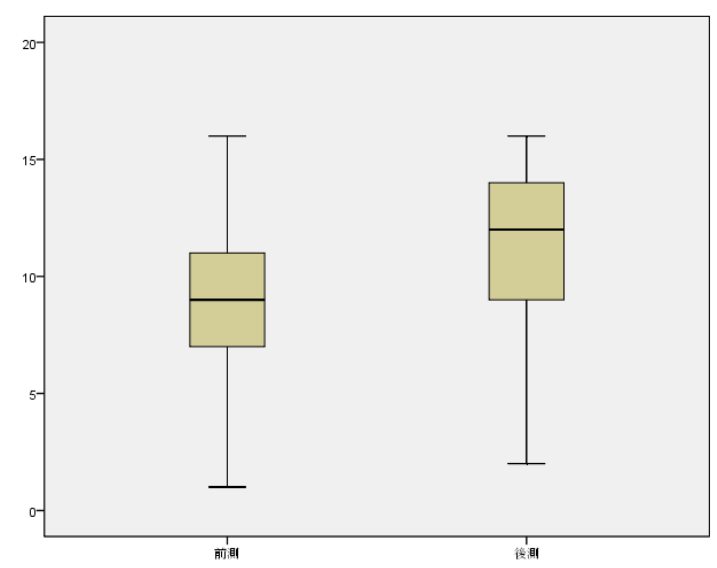

Figure 3. Box-and-whisker plot

\subsection{Comparison of Adults’ performance with students'}

There are 44 adults, including teachers, and 350 students in all attendants. Table 3 shows the results of both pretest and post-test grades. The mean value of pretest for adults is 4.3 points higher than those of students', while the mean value of post-test for adults 3 points higher than those of students'. In addition, comparing the percentage of right answers, the performance of secondary school teachers is the best.
Table 3. Group Statistics

\begin{tabular}{|l|l|r|r|r|r|}
\hline & & \multicolumn{1}{|c|}{$\mathrm{N}$} & \multicolumn{1}{c|}{ Mean } & $\begin{array}{c}\text { Std. } \\
\text { Deviation }\end{array}$ & $\begin{array}{c}\text { Std. Error } \\
\text { Mean }\end{array}$ \\
\hline \multirow{2}{*}{$\begin{array}{l}\text { Post } \\
\text { test }\end{array}$} & 1 & 44 & 13.9773 & 2.40628 & .36276 \\
\cline { 2 - 6 } & 2 & 350 & 10.9543 & 2.79340 & .14931 \\
\hline \multirow{2}{*}{$\begin{array}{l}\text { Pre- } \\
\text { test }\end{array}$} & 1 & 44 & 13.2045 & 1.94792 & .29366 \\
\cline { 2 - 6 } & 2 & 350 & 8.9057 & 2.60476 & .13923 \\
\hline
\end{tabular}

\subsection{K-12 teachers' performance}

In order to find out which factors are related to the pretest and protest grade, a linear regression module was set in this study. The factors include position, organization, and interest. Factors were selected by stepwise regression to know which factor have correlation to the pretest and protest grade. Taking the pretest grade as a response variable, the module is $y=13.661-3.6 x_{1}+0.985 x_{2}+0.256 x_{3}$. On the other hand, taking the protest grade as a response variable, the module is $y=11.962+1.177 x_{1}$ $2.174 x_{2}+0.412 x_{3}$. Table 4 shows that position and grade has negative correlation in pretest, which means the adults' grade is higher than those of children. Organization and grade has positive correlation, which means those who severed in the higher organization or school have higher grade. People, who are more interested in this exhibition, have higher grade also. Comparing the factors of pretest grade to those of protest grade, we find that position and organization have higher correlation to the grade.

Table 4. Correlation coefficients of pretest and protest

\begin{tabular}{|c|c|c|c|c|c|c|c|c|c|c|}
\hline \multicolumn{11}{|c|}{ Pretest Correlation Coefficients } \\
\hline \multirow[b]{2}{*}{ Model } & \multicolumn{2}{|c|}{$\begin{array}{c}\text { Unstandardized } \\
\text { Coefficients }\end{array}$} & \multirow{2}{*}{$\begin{array}{c}\text { Standardized } \\
\text { Coefficients } \\
\text { Beta }\end{array}$} & \multirow[b]{2}{*}{$\mathrm{t}$} & \multirow[b]{2}{*}{ Sig. } & \multicolumn{3}{|c|}{ Correlations } & \multicolumn{2}{|c|}{$\begin{array}{c}\text { Collinearity } \\
\text { Statistics }\end{array}$} \\
\hline & B & $\begin{array}{l}\text { Std. } \\
\text { Error }\end{array}$ & & & & $\begin{array}{l}\text { Zero- } \\
\text { order }\end{array}$ & Partial & Part & Tolerance & VIF \\
\hline (Constant) & 13.661 & 1.022 & & 13.373 & .000 & & & & & \\
\hline Position & -3.600 & .418 & -.395 & -8.612 & .000 & -.471 & -.400 & -.370 & .880 & 1.136 \\
\hline Organization & .985 & .213 & .211 & 4.614 & .000 & .352 & .228 & .198 & .880 & 1.136 \\
\hline Interest & .256 & .086 & .129 & 2.989 & .003 & .146 & .150 & .129 & .999 & 1.001 \\
\hline \multicolumn{11}{|c|}{ Protest Correlation Coefficients } \\
\hline (Constant) & 11.962 & 1.084 & & 11.032 & .000 & & & & & \\
\hline Position & 1.177 & .227 & .250 & 5.196 & .000 & .337 & .254 & .234 & .880 & 1.136 \\
\hline Organization & -2.174 & .444 & -.236 & -4.900 & .000 & -.328 & -.241 & -.221 & .880 & 1.136 \\
\hline Interest & .412 & .091 & .205 & 4.534 & .000 & .219 & .224 & .205 & .999 & 1.001 \\
\hline
\end{tabular}


Table 5. Different group's performance for questions

\begin{tabular}{|c|c|c|c|c|c|c|c|c|c|c|c|c|c|c|c|c|c|}
\hline Question & & 1 & 2 & 3 & 4 & 5 & 6 & 7 & 8 & 9 & 10 & 11 & 12 & 13 & 14 & 15 & 16 \\
\hline \multirow{3}{*}{$\begin{array}{l}\text { Elementary } \\
\text { school } \\
\text { teachers }\end{array}$} & $\mathrm{N}$ & 13 & 13 & 13 & 13 & 13 & 13 & 13 & 13 & 13 & 13 & 13 & 13 & 13 & 13 & 13 & 13 \\
\hline & Sum & 10.00 & 6.00 & 13.00 & 13.00 & 12.00 & 12.00 & 13.00 & 3.00 & 11.00 & 11.00 & 13.00 & 11.00 & 13.00 & 12.00 & 12.00 & 13.00 \\
\hline & ratio & $76.9 \%$ & $69.2 \%$ & $76.9 \%$ & $46.1 \%$ & $100 . \%$ & $100 . \%$ & $92.3 \%$ & $92.3 \%$ & $100 . \%$ & 23.\% & $84.6 \%$ & $84.6 \%$ & $100 . \%$ & $84.6 \%$ & $100 . \%$ & $92.3 \%$ \\
\hline \multirow{3}{*}{$\begin{array}{l}\text { Junior high } \\
\text { school } \\
\text { teachers }\end{array}$} & $\mathrm{N}$ & 12 & 12 & 12 & 12 & 12 & 12 & 12 & 12 & 12 & 12 & 12 & 12 & 12 & 12 & 12 & 12 \\
\hline & Sum & 8.00 & 10.00 & 10.00 & 10.00 & 10.00 & 10.00 & 10.00 & 4.00 & 10.00 & 10.00 & 10.00 & 10.00 & 10.00 & 10.00 & 10.00 & 10.00 \\
\hline & ratio & $80 \%$ & $100 \%$ & $100 \%$ & $100 \%$ & $100 \%$ & $100 \%$ & $100 \%$ & $40 \%$ & $100 \%$ & $100 \%$ & $100 \%$ & $100 \%$ & $100 \%$ & $100 \%$ & $100 \%$ & $100 \%$ \\
\hline \multirow{3}{*}{$\begin{array}{l}\text { Senior high } \\
\text { school } \\
\text { teachers }\end{array}$} & $\mathrm{N}$ & 1 & 15 & 15 & 15 & 15 & 15 & 15 & 15 & 15 & 15 & 15 & 15 & 15 & 16 & 16 & 16 \\
\hline & Sum & 12.00 & 9.00 & 12.00 & 12.00 & 12.00 & 12.00 & 12.00 & 2.00 & 12.00 & 12.00 & 12.00 & 12.00 & 11.00 & 11.00 & 12.00 & 10.00 \\
\hline & ratio & $100 \%$ & $75 \%$ & $100 \%$ & $100 \%$ & $100 \%$ & $100 \%$ & $100 \%$ & $16.6 \%$ & $100 \%$ & $100 \%$ & $100 \%$ & $100 \%$ & $91.6 \%$ & $91.6 \%$ & $100 \%$ & $83.3 \%$ \\
\hline
\end{tabular}

According to the position and organization, we separate the testers into 3 groups, elementary school teachers, junior high school teachers, and senior high school teachers. From each group's rate of right answers, we find that teachers in junior high schools have great performance as shown in Table 5. Also each group has improvement in posttest compared to the grade of pretest.

\subsection{Satisfaction survey}

The following is the Pie chart of the satisfaction survey of the attendants. In the pie charts, the percentages of satisfaction (yellow area) and highly satisfaction (red area) are very high. Over all, most attendants are satisfied to this Nanotechnology hands-on works exhibition.

According to the following data analysis, the following results are obtained in this study.

(1) The mean values of the grade are obviously different between pretest and post-test. The grade of post-test is higher than that of pretest. The Nanotechnology hands-on works exhibition can bring more knowledge to K-12 teachers and students from this study. It shows that holding a science exhibition could gain learning achievement to K-12 students.

(2) The mean values of the pretest and post-test grades are obviously different between adults and kids. Moreover, people who are more interested in nanotechnology would have higher grade in the tests.

(3) Over all, most visitors are satisfied to this Nanotechnology hands-on works exhibition.
Table 6 . The satisfaction survey (1 highly unsatisfied, 2 unsatisfied, 3 no comments, 4 satisfied, 5 highly satisfied)

\begin{tabular}{|l|l|}
\hline \multicolumn{1}{|c|}{ Item } \\
1. introduction \\
and guide \\
\hline 2. display of the \\
works
\end{tabular}




\section{Conclusions}

This study showed that science exhibition is a good way to enhance K-12 students' science knowledge. Library is an appropriate place for promoting popularization of science education. Through the abundant resources in the library, students and teachers can search and find the related information for their study and instruction. Holding the hand-on works exhibition in library, students and teachers can extend their knowledge of nanotechnology. However, for some students in secondary schools having the basic knowledge of nanotechnology, common contents of exhibition could not satisfy their needs. Improving the contents and extent of nanotechnology knowledge is advised for the future exhibition.

The problem-based learning is a popular learning method in recent years. By holding this kind of science hands-on works exhibition, students and teachers discussed together to complete their works. Students gain more knowledge and methods of learning how to solve problems by themselves from their progresses in hands-on activity. In this paper, K-12 teachers designed the instructions for nanotechnology concepts to arouse students' interests on nanotechnology. The instruction contents included different materials with different kinds of activities. For example, when explaining the waterresistance clothing and the related lotus effect theory, teachers made the slides to teach students the concept of lotus effect, and then showed the real lotus leaves to students. By observing the concrete samples, students could learn concepts for the abstract theory. After that, students did the hands-on works by themselves. Students also learned how to communicate with their classmates and teachers when doing the hands-on works. It is also an opportunity for students to practice the collaborated teamwork.

In the future, there are more issues worth discussing, such as gaining more subject samples to do the study, improving the questionnaire, and developing more appropriate way for the science exhibition.

\section{Acknowledgements}

The authors are grateful to the support from National Science Council, Taiwan, R. O. C., through grant NSC-99-2120-S-007-001-NM. The authors would also like to thank the help from Ms. Hui-Ting Yang and staff of library, National Tsing Hua University and seed teachers of local elementary and secondary schools for running the Nanotechnology hands-on works exhibition.

\section{References}

[1] Wikipedia, the free encyclopedia-Nanotechnology http://en.wikipedia.org/wiki/Nanotechnology. (Access date: 12 December 2010)

[2] S.Y. Stevens, L.A.M. Sutherland, and J.S. Krajcik, The Big Ideas of Nanoscale, Science \& Engineering-A Guidebook for Secondary Teachers, National Science Teachers Association Press, Arlington, Virginia, 2009.

[3] President's Council of Advisors on Science and Technology (PCAST), 2005, The national nanotechnology initiative at five years: Assessment and recommendations of National Nanotechnology Advisory Panel. www.nanoand-society.org/NELSI/entity/us_govt/NHI.html

[4]C.C. Wu, "The training of the nanotechnology education”, Enews, Magazine Association of Taipei, 2004/6/24 (in Chinese)

[5] F.O. Tsai, Teaching Nanotechnology through Information Technology Integrated Instruction in the Elementary School, Master's thesis, National Taichung University of Education, Taiwan, 2005. (in Chinese)

[6]S.Y. Kuo, Psychology and Educational Measurement, Ching-hua Press, Taipei, 2004. (in Chinese)

[7] M. Savin-Baden, "Problem-based learning in electronic engineering: locating legends or promising problems?"International Journal of Electrical Engineering Education, 2008, Vol. 45(2), pp. 96-204.

[8] P.S. Lin, The Effectiveness of Problem-Based Learning Sheet on Learning Achievement of Seventh Graderson Visiting the National Taiwan Science Education Center, Master's thesis, National Taiwan Normal University, Taiwan, 2008. (in Chinese)

[9] K. Goodnough, "Issues in modified problem-based learning: A self-study in pre-service science-teacher education", Canadian Journal of Science, Mathematics, \& Technology Education,2005, Vol. 5, pp. 289-306.

[10] J.L. Iglesias, "Problem-based learning in initial teacher education”, Prospects, 2002, Vol. 32(3), pp. 319332.

[11] R. Hider, "Differential white cell counts: an e-learning resource”, Bioscience Horizons, 2010, Vol. 3(1), pp. 10-20.

[12] D. Kilroy, "Problem based learning", Emergency Medicine Journal, 2003, Vol. 22, pp. 411-413.

[13] G. Maudsley, "Roles and responsibilities of the problem-based learning tutor in the undergraduate medical curriculum”, British Medical Journal, 1999, Vol. 318, pp. 657-661.

[14] H.Y. Hsu, "The modern significant and concrete behavior of Information Technology Integrated into Instruction”, Instruction Technology and Media, 2002, Vol. 60, pp. 54-67. (in Chinese) 
[15] J.S. Brown, A. Collins, and P. Duguid, "Situated cognition and the culture of learning", Educational Researcher, 1989, Vol. 18(1), pp. 322-342.

[16] Y.H. Cho, The research on guiding $8^{\text {th }}$ graders' to participate in science fair by using inquiry-based teaching strategy,Master's thesis, National Changhua University of Education, Taiwan, 2008.(in Chinese)

[17] H.P. Huang, “The science fair activities in elementary school”, Science Education and Development, 1996, Vol. 2, pp. 3-33.

[18] H.M. Anderson, Dale's Cone of Experience, University of Kentucky, USA

http://pharmacy.mc.uky.edu/faculty/resources/files/Step\%2 0Dales\%20Cone.pdf (Access date: 11 December 2010)

[19] E. Dale, Audiovisual Methods in Teaching, Dryden Press, NY, 1969. 